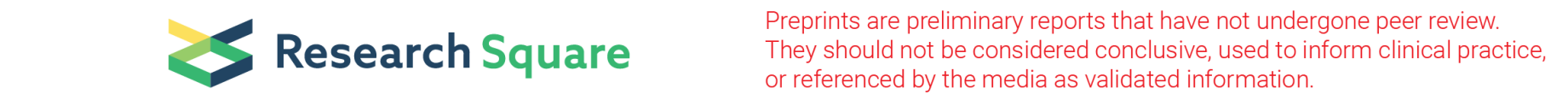

\title{
Sunflower Seed Meal and Probiotics in Short-term Feeding of Laying Hens
}

\section{Yasir Ditta}

UC Davis: University of California Davis

\section{Sadia Naseem}

University of CA, Davis

Ketwee Saksrithai

Univerisity of CA, Davis

Annie J. King ( $\square$ ajking@ucdavis.edu )

Department of Animal Science University of California 1 Shields Avenue Davis, CA 95616 https://orcid.org/0000-0003-3000-2157

\section{Research}

Keywords: laying hens, probiotics, sunflower seed meal, growth performance, egg quality

Posted Date: January 5th, 2021

DOI: https://doi.org/10.21203/rs.3.rs-136873/v1

License: (c) (i) This work is licensed under a Creative Commons Attribution 4.0 International License. Read Full License 


\section{Abstract}

\section{Background}

Horticultural byproducts may be used to partially or completely replace more expensive soy and corn while providing adequate energy and protein for broilers and laying hens. Probiotics, such as lactic acid bacteria, may aid in digestion of fibrous byproducts such as sunflower seed meal containing complex carbohydrates that along with some amino acids may not be easily digested by monogastric animals. Thus, byproducts and probiotics, when fed to poultry, may improve the production of nutritious meat and eggs.

$\underline{\text { Results }}$

White Leghorn Crosses (64 layers at 65- to 74-wk-old) were fed one of four diets for four weeks. Diets were (1) a corn/soy Control, (2) Control + $20 \%$ sunflower seed meal (SFM), (3) Control + Probiotics (Lactobacillus plantarum, rhamnosus, and paracasei - each at $>23.3 \mathrm{Mil}$ CFU/g for a total of approximately 70,000,000 Mil CFU/g added in drinking water), and (4) Control $+20 \% \mathrm{SFM}+$ Probiotics. Significance $(P \leq 0.05)$ and trends $(P \leq 0.10)$ were determined for production measurements as well as external and internal egg quality parameters. Diet did not significantly affect production measurements. There were trends due to Probiotics*Week for FCR and SFM*Probiotics*Week for feed intake. For external egg quality, SFM significantly increased egg weight, decreased specific gravity, and caused a downward trend for egg shell thickness. SFM*Week produced a significant effect on specific gravity. Probiotics significantly increased egg weight and egg shell weight while decreasing egg shell thickness; there was a trend due to temporal effects on specific gravity. For internal egg quality, SFM, SFM*Week, Week, and SFM*Probiotics*Week significantly affected yolk color. Week affected all internal measurements and SFM*Week caused weekly fluctuations, thereby producing a trend for Haugh unit.

$\underline{\text { Conclusions }}$

Diet had no effect on production measurements. SFM increased egg weight and decreased specific gravity; Probiotics increased egg weight, shell weight, and shell thickness. Future research in needed to assess production and egg quality parameters when feeding various fiber types, the digestibility of SFM/Probiotic diets, and colonization of varying quantities of probiotics (added in water and feed) in the gut of various types and ages of laying hens.

\section{Background}

Due to the price variation in soybean meal and corn, poultry nutritionists seek partial or complete replacement for these ingredients with nutritious, lower priced horticultural byproducts in least cost formulations to increase profit margins [1]. Sunflower is a high oil-yielding seed crop which can be cultivated two to three times in tropical areas and is highly adaptive to various climates [2]. Sunflower seed meal (SFM), a rendered byproduct from the sunflower oil industry, is an inexpensive alternate source of vegetable protein and, possibly, energy for animals [2, 3]. The crude protein content of SFM, ranging from 29 to $45 \%$, is inversely related to its crude fiber content (14 to $32 \%$ ) and depends on de-hulling and oil extraction processes [4].

There are limits for use of SFM in feed for poultry and other monogastric animals because its high fiber content is not fully metabolized [5, 6]. As well, a lysine deficiency, a low digestion coefficient for lysine, and a negative correlation between fiber content and total metabolizable energy of SFM were reported [4, 7]. Enzymes could be added to diets to enhance digestibility of SFM; another possibility is inclusion of probiotics, live microbial non-digestible supplements that can colonize the intestine and ceca of poultry [8].

The major genera of bacteria involved in carbohydrate fermentation are Bacteroides, Bacillus Bifidobacterium, and Lactobacillus [9, 10]. Upon consumption, lactic acid bacteria are delivered into the gastrointestinal tract where they modify the intestinal milieu; and, if colonized, they increase the levels of amylase needed for catalysis of starch to sugars [11]. They can improve feed efficiency, productivity of laying hens, and egg quality measurements [12]. Due to recent advancements (solvent extraction and de-hulling techniques [13]) in SFM production and use of Lactobacillus probiotics for livestock, we investigated their short-term (four week) use, alone and in combination, to determine their efficacy on performance and external/internal egg quality for older layers.

\section{Materials And Methods}

Sunflower seed meal (SFM, Table 1) was procured from the National Sunflower Association (NSA, Mandan, ND, USA). The nutrient composition of the meal was provided by NSA and used in formulation of diets. Ethoxyquine (150 ppm), an antioxidant, was added to SFM during manufacture of the meal. Upon receipt, the meal was immediately stored at $-20^{\circ} \mathrm{C}$ until use. 
Table 1

Nutrient composition ${ }^{1}$ of sunflower seed meal.

\begin{tabular}{|c|c|}
\hline Nutrients & $\mathrm{Kcal} / \mathrm{kg}$ \\
\hline $\mathrm{ME}^{2}$ & 318.2 \\
\hline \multirow[t]{2}{*}{ True ME } & 347.7 \\
\hline & $\%$ \\
\hline Moisture & 10.00 \\
\hline Crude fat & 1.8 \\
\hline Crude fiber & 25.00 \\
\hline Ash & 7.15 \\
\hline $\mathrm{NF}^{3}$ & 20.35 \\
\hline Calcium & 0.27 \\
\hline Total Phosphorus & 1.10 \\
\hline P (Available) & 0.32 \\
\hline Inherent Fat & 0.30 \\
\hline Sodium $+\mathrm{KCl}$ & 0.02 \\
\hline Potassium & 1.00 \\
\hline Chloride & 0.01 \\
\hline Lysine & 1.20 \\
\hline Methionine + cysteine & 1.24 \\
\hline Leucine & 1.96 \\
\hline Threonine & 1.29 \\
\hline Isoleucine & 1.29 \\
\hline Tryptophan & 0.33 \\
\hline Valine & 1.57 \\
\hline Choline & 1.50 \\
\hline
\end{tabular}

\section{Probiotics in Drinking Water}

Sources of (1) water for mixing probiotics and (2) the viable count of bacteria added were analyzed by Michelson Laboratories, Inc. (Commerce, CA, USA). Available water was double distilled, distilled, and chlorinated. The manufacturer (Living Streams Mission, Athol, Idaho) of probiotics also advised using chlorinated water with $\mathrm{CuSO}_{4}(1 \mathrm{ppm})$ for mixing of bacteria. Heavy metals in chlorinated water were analyzed (UC Davis Analytical Laboratory, Davis, CA). As discussed in Results below, probiotics - active Lactobacillus plantarum, rhamnosus, and paracasei - were added daily to chlorinated water at > 23.3 Mil CFU/g, totaling approximately 70,000,000 Mil CFU/g.

\subsection{Diet}

White Leghorn Crosses (64 hens ranging in age from 65- to 74-week-old) were monitored to ensure consistency of weight and egg production. Data was collected for weight (two weeks) and egg production (nine days) prior to beginning the study. Layers of similar weight (1.59 kg, RMS = $0.0804, P<0.05)$ and egg production of (5.67 eggs per week, RMS $=1.391, P<0.05$ ) were randomly divided into four treatments $\times$ four replications $\times$ four laying hens/replication and fed either the Control (a corn/soy diet), Control $+20 \%$ SFM, Control + Probiotics in drinking water, or Control + $20 \%$ SFM + Probiotics in drinking water for four weeks [14, Table 2]. Feed and water were administered ad libitum. Layers were singly housed in cages $(45.72 \mathrm{~cm} \times 45.72 \mathrm{~cm} \times 53.34 \mathrm{~cm})$. Hens were provided 16 hours of light and 8 hours of darkness throughout the trial, conducted in June and July in Davis, CA. The average temperature in the layer house was $70.19{ }^{\circ} \mathrm{C} \pm 4.8$. The Institutional Animal Care and Use Committee (UC Davis, Davis, CA) approved the protocol for feeding and care. 
Table 2

Formulation and nutrients composition of diets containing $20 \%$ sunflower seed meal (SFM) ${ }^{1}$ and the Control $^{2}$

\begin{tabular}{|c|c|c|c|c|c|}
\hline \multirow[t]{2}{*}{ Feed Ingredients } & \multicolumn{4}{|c|}{ Nutrients Composition of Feed } & \multirow[b]{2}{*}{ Control } \\
\hline & $20 \%$ SFM & Control & & $20 \%$ SFM & \\
\hline Corn & 52.14 & 68.48 & Moisture & 10.79 & 12.07 \\
\hline SFM & 20 & 0.00 & $\mathrm{ME}^{4}(\mathrm{Kcal} / \mathrm{lb})$ & 1359.9 & 1351.14 \\
\hline Limestone & 9.652 & 9.582 & True ME (Kcal / lb) & 1425 & 1425 \\
\hline Blended fat & 8.684 & 2.893 & Crude protein & 14.99 & 13 \\
\hline Soybean meal & 8.001 & 17.371 & Crude fat & 10.27 & 5.01 \\
\hline Nexfos & 0.997 & 1.163 & Crude fiber & 6.58 & 2.32 \\
\hline $\mathrm{NaCl}$ & 0.152 & 0.149 & Ash & 12.1 & 11.48 \\
\hline DL-methionine & 0.087 & 0.163 & Arginine & 0.9581 & 0.818 \\
\hline L-lysine $\mathrm{HCl}$ & 0.086 & 0.00 & Lysine & 0.643 & 0.6432 \\
\hline Vitamin premix ${ }^{3}$ & 0.075 & 0.075 & Methionine & 0.37 & 0.37 \\
\hline Choline-HCl & 0.075 & 0.075 & Methionine and Cysteine & 0.58 & 0.5875 \\
\hline Mineral premix 3 & 0.05 & 0.05 & Tryptophan & 0.1571 & 0.1637 \\
\hline \multirow[t]{14}{*}{ Total } & 100 & 100 & Leucine & 1.08 & 1.14 \\
\hline & & & Isoleucine & 0.5955 & 0.6204 \\
\hline & & & Threonine & 0.5346 & 0.4955 \\
\hline & & & Valine & 0.6651 & 0.6204 \\
\hline & & & Calcium & 4 & 4 \\
\hline & & & Available Phosphorus & 0.31 & 0.31 \\
\hline & & & Phytic Phosphorus & 0.5842 & 0.4931 \\
\hline & & & Added fat & 8.68 & 2.89 \\
\hline & & & Sodium & 0.152 & 0.1629 \\
\hline & & & Chloride & 0.15 & 0.15 \\
\hline & & & Choline & 0.727 & 0.5653 \\
\hline & & & Potassium & 0.555 & 0.6108 \\
\hline & & & Linoleic Acid & 3.15 & 2.04 \\
\hline & & & ${ }^{5} \mathrm{Na}+\mathrm{K}-\mathrm{Cl}(\mathrm{mEq} / \mathrm{Kg})$ & 162.47 & 180.55 \\
\hline \multicolumn{6}{|c|}{ 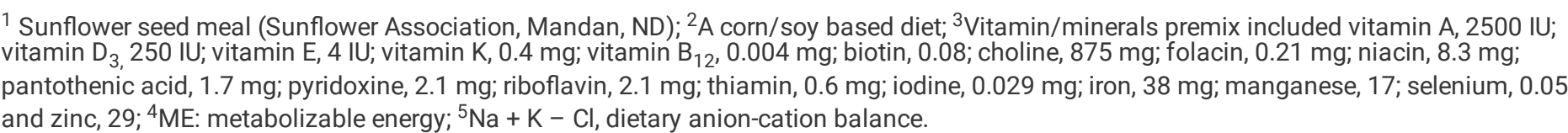 } \\
\hline
\end{tabular}

\subsection{Production and Egg Quality Measurements}

Weekly feed intake and body weight were measured and the feed conversion ratio, FCR (feed intake/kg dozen eggs) was determined for each diet. Eggs were collected daily and stored at $4{ }^{\circ} \mathrm{C}$. Weekly egg quality was measured within 6 to 24 hours after collection. External measurements included egg weight; specific gravity (salt bath method), [15]; shape index (egg width/egg length $\times 1000$ ), [16]; egg shell weight; and egg shell thickness [17].

Internal measurements included egg yolk color (Roche Yolk Color Fan), [18]; egg yolk index (egg yolk height/egg yolk diameter $\times$ 100), [19]; albumen index (albumen height/average egg albumen width $\times 100$ ), [20]); yolk to albumen ratio (egg yolk weight/weight of albumen), [20]; Haugh unit, calculated as $100 \times \log$ (albumen height $-1.7+$ egg weight ^ $0.37+7.57$, [21]; and proportional albumen ratio (egg albumen weight/egg weight $\times 100$ ). 


\subsection{Statistical Analysis}

A power analysis was conducted to determine the adequate number of layers for this study. With a confidence interval at $50 \%$ (for which one-half of the layers were fed probiotics) and a $95 \%$ confidence level, a population of 64 layers was determined to be adequate (22). Data as a $2 \times 2$ factorial (Probiotics*SFM, $n=6$ ) in an unbalanced mixed model design with Week as a repeated measure were analyzed using the Proc Mixed Procedure and the PDMIX800SAS Macro [23]. Probiotics (treatment name) was the main effect and SFM (treatment name) became the subplot effect. Pairwise comparisons of treatment means were conducted [23]. The Tukey-Kramer Adjustment was used to assess differences among means at $P \leq 0.05$. Significance at $P \leq 0.10$ was noted.

\section{Results}

\subsection{Probiotics in drinking water}

Table 3. Probiotics in sources of water.

\begin{tabular}{|c|c|c|c|}
\hline Water (1L) & & Lactic acid bacteria in L of water ${ }^{1}$ & $\begin{array}{l}\text { Probiotics } \\
156 \mathrm{uL} / \mathrm{L} \\
\text { added and detected }^{2}\end{array}$ \\
\hline Double distilled water & A & $<1$ & - \\
\hline Double distilled water & B & 270 & + \\
\hline Distilled water & & 160 & + \\
\hline Chlorinated water & & 160 & + \\
\hline Chlorinated water $+\mathrm{CuSO}_{4}(1 \mathrm{ppm})^{3}$ & & 13 & + \\
\hline
\end{tabular}

${ }^{1}$ Bacterial count for all sources of water (as is). ${ }^{2}+$ denotes presence of Probiotics as added (156 uL/L) in in water = double distilled (B), distilled, chlorinated, and chlorinated $+\mathrm{CuSO}_{4}\left({ }^{3}\right.$ Recommended by Living Streams Living Mission, Athol, Idaho), respectively; no probiotics were added to double distilled A.

As noted in Table 3, lactic acid bacteria was 270 count in double distilled water (not readily available at the grow-out facility) and 160 count in both distilled water from the laboratory and chlorinated drinking water in lines at the grow-out facility (Method COM ED.4 19.521, Michelson Laboratories, Inc., Commerce, CA, USA). Probiotics from the manufacturer were analyzed and found to contain the quantities noted ( 56.7g at 4 billion CFU). For ease of mixing and to avoid changes in the mineral content of diets, Probiotics were mixed in chlorinated drinking water, each at > 23.3 Mil CFU/g, totaling approximately 70,000,000 Mil CFU/g. Analysis revealed no concentration of heavy metals to affect the viability of probiotics in chlorinated drinking water (Table 4).

Table 4. Soluble minerals analysis ${ }^{1}$ of chlorinated drinking water.

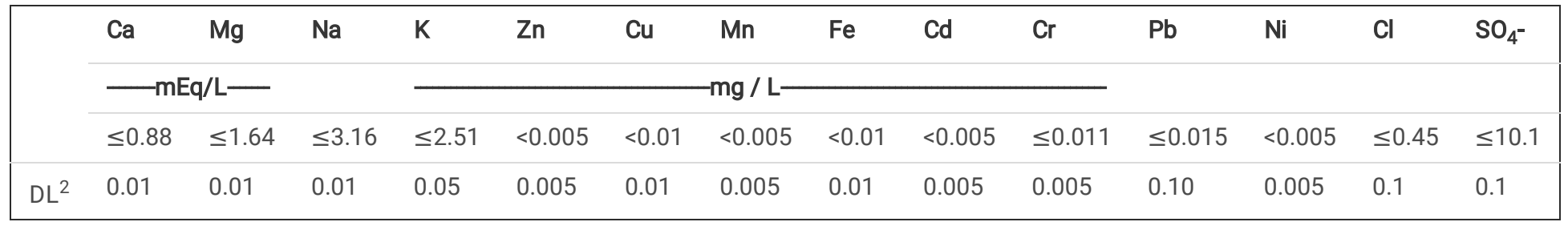

${ }^{1}$ Analytical Laboratory, UC (Davis, CA, USA). ${ }^{2}$ Detection limit. 
Table 5. Major effects ${ }^{1}$ of Control $^{2}, \mathrm{SFM}^{2}$, and Probiotic $^{3}$ on production parameters of laying hens during four weeks.

\begin{tabular}{|llll|}
\hline Major Effects & $\begin{array}{l}\text { Feed Intake } \\
(\mathbf{g} / \mathrm{hen} / \mathrm{d})\end{array}$ & Egg Production (\%) & FCR \\
\hline SFM & & & \\
\hline Control & 83.90 & 65.32 & 1.60 \\
\hline $20 \%$ SFM & 81.56 & 61.69 & 1.63 \\
\hline SE & 1.71 & 1.73 & 0.05 \\
\hline$P$ value & 0.3255 & 0.1323 & 0.5909 \\
\hline Probiotic & & & 1.59 \\
\hline Control & 81.52 & 63.19 & 1.64 \\
\hline $156 \mu L / L$ & 83.94 & 63.82 & 0.05 \\
\hline SE & 1.79 & 1.87 & 0.6011 \\
\hline$P$ value & 0.3588 & 0.8207 & 0.1063 \\
\hline & $P$ values & & 0.4828 \\
\hline SFM*Probiotics & 0.4448 & 0.7856 & 0.0002 \\
\hline Week & 0.0011 & 0.0070 & 0.7562 \\
\hline SFM*Week & 0.9302 & 0.7391 & 0.2034 \\
\hline Probiotics*Week & 0.1475 & 0.5823 & \\
\hline SFM*Probiotics*Week & 0.0615 & & \\
\hline
\end{tabular}

${ }^{1}$ Means with the same superscript are not significantly different a $P \leq 0.05$.

${ }^{2}$ Control (a corn/soy based diet) $+20 \%$, sunflower seed meal, SFM.

${ }^{3}$ Probiotics added to provide each at > 23.3 Mil CFU/g, totaling approximately 70,000,000 Mil CFU/g for all added species ( $L$. paracasei, $L$. plantarum, and L. rhamnosus) in chlorinated drinking water.

No mortality occurred during the four week study. SFM, Probiotics, and SFM*Probiotics had no effect on feed intake, egg production, or FCR while Week was significant for all production measurements (Table 5). There were trends due to SFM*Probiotics*Week for feed intake $(p=0.0615)$ and Probiotics*Week for FCR $(p=0.0979)$ caused by fluctuations in measurements over time.

\subsection{External egg quality}

Table 6. Major effects ${ }^{1}$ of Control $^{2}$, SFM $^{2}$ and Probiotics ${ }^{3}$ on external quality of eggs from laying hens during four weeks. 


\begin{tabular}{|llllll|}
\hline Major Effects & $\begin{array}{c}\text { Egg Weight } \\
(\mathbf{g})\end{array}$ & Specific Gravity & Shape Index & $\begin{array}{c}\text { Egg Shell Weight } \\
(\mathbf{g})\end{array}$ & $\begin{array}{l}\text { Egg Shell Thickness } \\
(\mathrm{mm})\end{array}$ \\
\hline SFM & & & & & \\
\hline Control & $53.40^{\mathrm{b}}$ & $1.0842^{\mathrm{a}}$ & 0.84 & 5.04 & 0.35 \\
\hline $20 \%$ & $54.35^{\mathrm{a}}$ & $1.0826^{\mathrm{b}}$ & 0.84 & 5.06 & 0.34 \\
\hline SE & 0.27 & $4.40 \times 10^{-4}$ & $3.37 \times 10^{-3}$ & 0.02 & $1.70 \times 10^{-3}$ \\
\hline$P$ value & 0.0242 & 0.0082 & 0.3946 & 0.6331 & 0.0581 \\
\hline Probiotics & & & & & \\
\hline Control & $53.33^{\mathrm{b}}$ & $1.0843^{\mathrm{a}}$ & 0.84 & $5.02^{\mathrm{b}}$ & $0.35^{\mathrm{a}}$ \\
\hline 156HL/L & $54.42^{\mathrm{a}}$ & $1.0826^{\mathrm{b}}$ & 0.84 & $5.08^{\mathrm{a}}$ & $0.34^{\mathrm{b}}$ \\
\hline SE & 0.28 & $4.42 \times 10^{-4}$ & $3.37 \times 10^{-3}$ & 0.02 & $1.72 \times 10^{-3}$ \\
\hline$P$ value & 0.0411 & 0.0789 & 0.7799 & 0.0441 & 0.0109 \\
\hline & $P$ value & & & & 0.9335 \\
\hline SFM*Probiotics & 0.7356 & 0.0683 & 0.1819 & 0.1002 & 0.0280 \\
\hline Week & 0.0010 & $<0.0001$ & 0.0540 & 0.0011 & 0.4270 \\
\hline SFM*Week & 0.7595 & 0.0301 & 0.9812 & 0.6710 & 0.1550 \\
\hline Probiotics*Week & 0.6701 & 0.8936 & 0.5354 & 0.9459 & 0.4075 \\
\hline SFM*Probiotics*Week & 0.8510 & 0.3411 & 0.5769 & 0.6181 & \\
\hline
\end{tabular}

${ }^{1}$ Means with the same superscripts are not significantly different at $P \leq 0.05$.

${ }^{2}$ Control (a corn/soy based diet) $+20 \%$ sunflower seed meal (SFM).

${ }^{3}$ Probiotics added to provide each at > 23.3 Mil CFU/g, totaling approximately 70,000,000 Mil CFU/g of each species (L. paracasei, L. plantarum, and L. rhamnosus) in chlorinated drinking water.

SFM significantly increased egg weight $(p=0.0242)$ while decreasing specific gravity $(p=0.0082)$. There was a downward trend $(p=0.0581)$ for eggshell thickness. Temporal fluctuations were observed for SFM*Week where specific gravity was significantly affected $(p=0.0301)$ as shown in Tables 6 and 7. Due to temporal changes, SFM*Probiotics produced a trend for specific gravity at $p=0.0683$.

Table 7. Effects ${ }^{1}$ of SFM*Week on specific gravity of eggs from 65 - to 74-week-old laying hens.

\begin{tabular}{|lllll|}
\hline Diet & Week 1 & Week 2 & Week 3 & Week 4 \\
Control & 1.084 & 1.080 & 1.086 & 1.087 \\
$20 \%$ SFM $^{2}$ & 1.084 & 1.081 & 1.083 & 1.083 \\
\hline
\end{tabular}

${ }^{1}$ Means with the same superscript are not significantly different.

${ }^{2}$ Control (a corn/soy based diet) $+20 \%$ sunflower seed meal (SFM).

For Probiotics, there was a significant increase in egg weight $(p=0.0411)$ and egg shell weight $(p=0.0441)$ and a significant decrease in egg shell thickness $(p=0.0109)$. Specific gravity trended downward at $p=0.0789$. Week was significant for egg weight $(p=0.0010)$, egg shell weight $(p=$ $0.0011)$, and egg shell thickness ( $p=0.0280)$; it was highly significant for specific gravity $(p=<0.0001)$ and there was a temporal effect for shape index $(p=0.054)$. Probiotics*Week and SFM*Probiotics*Week had no effect on external egg quality parameters (Table 6). 


\subsection{Internal egg quality}

Table 8. Major effects ${ }^{1}$ of Control $^{2}$ SFM $^{2}$ and Probiotics ${ }^{3}$ on internal quality of eggs from layers fed for four weeks.

\begin{tabular}{|c|c|c|c|c|c|c|}
\hline Major Effects & Egg Yolk Color & Yolk Index & Albumen Index & Yolk:Albumen & Haugh Unit & Proportional Albumen \\
\hline \multicolumn{7}{|l|}{ SFM } \\
\hline Control & $7.55^{\mathrm{a}}$ & 41.84 & 6.77 & 55.46 & 72.99 & 57.27 \\
\hline $20 \%$ & $7.34^{b}$ & 41.16 & 6.69 & 55.63 & 73.62 & 57.52 \\
\hline SE & 0.05 & 0.33 & 0.15 & 0.56 & 0.63 & 0.23 \\
\hline$P$ value & 0.0074 & 0.1521 & 0.7020 & 0.8145 & 0.4943 & 0.3837 \\
\hline \multicolumn{7}{|l|}{ Probiotics } \\
\hline Control & 7.51 & 41.32 & 6.73 & 55.16 & 73.29 & 57.53 \\
\hline $156 \mu \mathrm{L} / \mathrm{L}$ & 7.39 & 41.69 & 6.74 & 55.93 & 73.32 & 57.26 \\
\hline SE & 0.05 & 0.34 & 0.15 & 0.63 & 0.62 & 0.25 \\
\hline \multirow[t]{2}{*}{$P$ value } & 0.1528 & 0.4515 & 0.9503 & 0.4285 & 0.9752 & 0.4723 \\
\hline & $P$ value & & & & & \\
\hline SFM*Probiotics & 0.7202 & 0.3551 & 0.3994 & 0.7373 & 0.1219 & 0.7304 \\
\hline Week & 0.0033 & $<0.0001$ & 0.0046 & 0.0347 & $<0.0001$ & $<0.0001$ \\
\hline SFM*Week & $<0.0001$ & 0.5676 & 0.4718 & 0.0254 & 0.4646 & 0.0554 \\
\hline Probiotics*Week & 0.7752 & 0.3029 & 0.3314 & 0.7948 & 0.0843 & 0.7943 \\
\hline SFM*Probiotics*Week & 0.0104 & 0.5959 & 0.3240 & 0.3894 & 0.1426 & 0.6207 \\
\hline
\end{tabular}

${ }^{1}$ Means with the same superscript are not significantly different. ${ }^{2}$ Control (a corn/soy based diet) $+20 \%$ sunflower seed meal (SFM). ${ }^{3}$ Probiotics added to provide each at $>23.3 \mathrm{Mil} \mathrm{CFU/g}$, totaling approximately 70,000,000 Mil CFU/g of each species (L. paracasei, $L$. plantarum, and $L$. rhamnosus) in chlorinated drinking water.

Table 8 shows internal quality measurements. SFM significantly decreased $(p=0.0074)$ yolk color by $2.78 \%$. SFM*Week was highly significant $(p$ $=<0.0001)$ for yolk color where week 2 (6.97) for 20\% SFM was significantly lower when compared to week 1 for the Control (7.64) (Data not shown). SFM*Week was significant $(p=0.0254)$ for yolk:albumen and caused a trend $(p=0.0554)$ for proportional albumen due to temporal changes. SFM*Probiotics*Week significantly affected $(p=0.0104)$ yolk color. Probiotics and SFM*Probiotics had no effects on internal quality. Week was highly significant $(p=<0.0001)$ for yolk index, Haugh unit, and proportional albumen. Also, Week was significant $(p=0.0033)$ for yolk color, albumen index $(p=0.0046)$, and yolk:albumen $(p=0.0347)$.

\section{Discussion}

\subsection{Production: SFM}

Our results are in agreement with those of several investigators who found no effect of SFM on production parameters. Uwayjan et al (1983) and Yalcın et al., (2008) reported no effect of 15\% SFM in the diet [24, 25]. Shi et al., (2012) found insignificant effects of diets supplemented with a greater quantity of SFM $(24.84 \%, 33 \%$ CP) [26]. Laudadio et al. (2014) also reported insignificant effects of SFM (IR, 16\%; CP, 42.3\%; and CF, $10.3 \%$ ) on laying hens for weight gain, feed consumption, egg production, and FCR [1]. Our findings and those of other investigators suggest that while SFM did not improve production parameters, there were no detrimental effects. Thus, SFM could be substituted for soybean meal in the diets of older layers.

\section{Production: Probiotics}

In our work, there were no effects of Probiotics alone on production parameters while results from other investigators reported improvements. Mohan et al. (1995) reported a quadratic increase in egg production for layers consuming diets supplemented with 0, 100, and 150 mg probiotics 
(Lactobacillus, Bifidobacterium, Aspergillus, and Torulopsis species at $27 \times 10^{9} \mathrm{cfu} / 10 \mathrm{~g}$ per kg diet) during the peak laying period [27]. Kurtoglu et al., (2004) fed BioPlus, a commercial multi-stain probiotic, at 250, 500, and $750 \mathrm{mg} / \mathrm{kg}$ feed, to 27-week-old Brown Nick layers and showed an increase in egg production [28]. Yörük et al. (2004) reported that after 90 days, egg production significantly improved with addition of $0.1 \%$ probiotics (Lactobacillus, Bifidobacterium, Streptococcus, and Enterococcus species) in the diet [29].

Investigators reported that the average time for colonization of the gut by various $B$. Subtilis species was three to six weeks in older hens [30]. Our results for Lactobacillus species seem to indicate that substantial colonization in the gut of older layers needs a period longer than 4 weeks to affect production measurements. Possibly, on-going competition of the Lactobacillus species with established organisms may have caused fluctuations in weekly results as discussed below for external and internal egg quality measurements. Alternatively, the quantity of bacterial species used may not have produced a significant enhancement for production measurements even after colonization in hens fed in our study.

As noted above, a lysine deficiency, a low digestion coefficient for lysine, and a negative correlation between fiber content and total metabolizable energy of SFM were reported [4, 7]. Probiotics (including the Lactobaccilus species) as live microbial non-digestible supplements can colonize in the intestine of animals as well as in the ceca of poultry [8]. If colonized, they increase amylase, causing catalysis of starch to sugars [11]. Also, due to enhanced digestibility and absorption of nutrients (including amino acids), they can improve feed efficiency, productivity of laying hens, and egg quality measurements [12]. Due to our hypothesis that Probiotics would improve digestion of SFM fibrous material and amino acids, there was no attempt to adjust digestible lysine and other amino acids across diets. No effect for SFM*Probiotics indicated that Lactobacillus species did not greatly enhance production parameters by increasing digestion of lignocellulosic compounds or digestibility of amino acids in SFM. Future work will include results for apparent digestibility of all diets to more accurately measure improvements in amino acid availability caused by Lactobacillus species alone and when coupled with SFM.

It was assumed that fluctuations by Week for feed intake and FCR of older layers likely contributed to trends noted for SFM*Probiotic*Week. To further investigate the effects of SFM and Probiotics on layer production parameters, investigations for Probiotics used herein and greater quantities should be conducted in drinking water and feed of young and old hens.

\subsection{External egg quality: SFM}

SFM increased egg weight. Karunajeewa et al. (1989) also reported that SFM increased egg weight of White Leghorn $\times$ Australorp hens fed for 24 to 64 weeks [31]. However, Shi et al. (2012) reported that feeding diets supplemented with SFM up to $24.84 \%$ for 6 weeks did not influence egg weight [26]. Yalcın et al. (2008) revealed that egg weight of hens fed a SFM or a soybean meal diet with 0 and $2 \mathrm{~g} / \mathrm{kg}$ commercial yeast culture product (Saccharomyces cerevisiae) for 16 weeks did not change [25]. Laudadio et al., 2014 noted that egg weight was statistically similar among eggs of hens fed soybean meal or a low-fiber SFM diet (CP, 42.3\%; CF, 10.3\% and IR, 16\%) for 10 week [1]. These contradictory findings suggest that effect of fiber types and quantities on external egg quality should be thoroughly investigated.

In our study, the decrease in specific gravity caused by SFM and SFM*Week was likely associated with the trend toward a decrease in egg shell thickness and greater egg mass due to age and less calcium deposition [32,33]. While eggshell thickness for SFM trended downward in the present study, it did not fall below $0.33 \mathrm{~mm}$, indicating that eggs had shells of adequate thickness that could withstand the rigors of marketing [34].

SFM had no effect on shape index. A high shape index indicates more eggs of rounded shape as opposed to more elongated ones [35]. Age by strain and season may have an effect on index with those from older hens and laid in summer and autumn having an elongated shape [35, 36]. However, all eggs in our study had an index of 84. Eggs with an index $>76$ can withstand the rigors of processing/packaging and transportation $[35,36]$.

\subsection{External egg quality: Probiotics}

Our finding for an increase in egg weight produced by Probiotics did not agree with those of Kurtoglu et al. (2004) who noted no effect [28]. However, Mohan et al. (1995) noted an improvement in egg weight for hens fed diets supplemented with probiotics for 10 weeks during the peak laying period [27].

As Probiotics increased egg weight, eggshell weight increased and eggshell thickness decreased. The decrease in eggshell thickness was validated by the trend toward a decline in specific gravity [33]. SFM*Probiotics affected specific gravity and eggshell weight; also, this may have been influenced by the age of hens. Investigators suggested that probiotics and SFM promoted growth of intestinal microflora, thereby producing a healthy gut lining causing improved digestion and subsequent deposition of nutrients in yolk (and greater weight) although mechanisms are not understood [37, 38]. More work with younger birds and/or greater quantities of Probiotics may help clarify these findings.

\subsection{Internal egg quality: SFM}

Egg Yolk color was decreased by SFM and affected by Week, SFM*Week, and SFM*Probiotics*Week. The decrease in color caused by SFM and temporal effects were likely due to dilution of dietary pigments in corn, as the major contributor of carotenoids, when $20 \%$ SFM was added [38, 39]. Fat at two times more in the SFM diet than in the Control may have caused some dilution of color as well.

Page 9/12 
The significant effect of SFM*Week on the yolk:albumen and proportional albumen may have indicated greater internal weight of the egg associated with increasing age. Even though there was greater mass over time, the Haugh unit, the standard for overall internal egg quality, remained low throughout the study. A Haugh unit for young layers is $>91$; that for older layers in our work was $\sim 73$. Fluctuation in Haugh units over time, as with some production and egg quality measurements, may have been related to intermittent colonization of Lactobacillus species during the 4-week period.

\section{Conclusion}

For significance at $P<0.05$, neither SFM, Probiotics, nor SFM*Probiotics affected production measurements. SFM increased egg weight and decreased specific gravity. The increase in egg and shell weight, was accompanied by a decrease in eggshell thickness, likely compounded by less calcium deposition as hens aged. A decrease in yolk color was due to addition of SFM that reduced pigments; increased fat content in SFM diets likely caused a diluting effect as well. SFM*Probiotics affected some external egg quality measurements at $P<0.01$, but had no effect on internal egg quality. Week (age of hens) affected production and external/internal measurements. More work is needed to clearly establish (1) the effect of various fiber types on production and egg quality parameters, (2) the digestibility of SFM/Probiotic diets, and (3) time needed for colonization of various quantities of probiotics (added in water and feed) in the gut of various types and ages of laying hens.

\section{Declarations}

Author Contributions: Project Administration and funding acquisition, AJK; Methodology, Y.A.D.; K.S.; S.N.; Formal analysis, Y.A.D., S.N; Original draft, Y.A.D.; Review and editing, A.J.K.

Funding: This research was funding the California Agricultural Experiment Station.

Acknowledgement: The authors wish to thank Jackie Pisenti, Ph.D. and staff at the Hopkins Avian Facility, University of CA, Davis, CA (USA).

Conflicts of Interest: The authors declare no conflicts of interest.

Protocol was approved by the Animal Care and Use Committee at the University of California (Davis, CA).

Consent for publication - All authors have given consent to publish.

Availability of data and materials - Data is available from Dr. Yasir Ditta, an author.

Competing interests - There are no competing interests.

Funding - Funding was provided by the CA Agricultural Experiments Station.

Authors' contributions - All authors participated in the design and performance of the study.

Authors Ditta and Naseem performed experimental analysis. Author Saksrithai helped with revision of the manuscript. Author King approved the final design and revised the manuscript.

Acknowledgements - Authors acknowledge the help and advice of personnel at the Hopkins Avian Unit, University of CA (Davis, CA).

\section{References}

Rohrmann S, Overvad K, Bueno-de-Mesquita HB, Jakobsen MU, Egeberg R, Tjønneland A, et al. Meat consumption and mortality - results from the European Prospective Investigation into Cancer and Nutrition. BMC Med. 2013;11:63.

Article within a journal by DOI

Slifka MK, Whitton JL. Clinical implications of dysregulated cytokine production. Dig J Mol Med. 2000; doi:10.1007/s801090000086.

1. Laudadio V, Ceci E, Lastella NMB, Tufarelli V. Effect of feeding low-fiber fraction of air-classified sunflower (Helianthus annus L.) meal on laying hen productive performance and egg yolk cholesterol. Poult. Sci. 2014;93:2864.

2. Ravindran V, Blair R. Feed resources for poultry production in Asia and the Pacific. II. Plant protein sources. World Poult. Sci. J. $1992 ; 48: 205$.

3. Kalmendal R, Elwinger K, Holm L, Tauson R. High fibre sunflower cake affects small intestinal digestion and health in broiler chickens. Brit. Poult. Sci. 2011;52: 86.

4. Moghaddam, H.N.; Salari, S.; Arshami, J.; Golian, A.; Maleki, M. Evaluation of the nutritional value of sunflower meal and its effect on performance, digestive enzyme activity, organ weight, and histological alterations of the intestinal villi of broiler chickens. J. Appl. Poult. Res. 2012;2:293. 
5. Brenes A, Centeno C, Viveros A, Arija I. 2008. Effect of enzyme addition on the nutritive value of high oleic acid sunflower seeds in chicken diets. J. Poult. Sci. 2008;87:2300.

6. King, A. J. Removal of Excess Cellulose and associated polysaccharides in fruit and vegetable by-produce - Implication for use in feed for monogastric farm animals. In: G.M. Van De Ven TGM, editor. Cellulose - Fundamental Aspects. Rijeeka: InTech Europe: 2012.p 249-259.

7. Villamide MJ, San Juan LD. Effect of chemical composition of sunflower seed meal on its true metabolizable energy and amino acid digestibility. J. Poult. Sci. 1998;77:1884.

8. Gibson GR, Roberffroid MB. Dietary modulation of the human colonic microbiota: introducing the concept of prebiotics. J. Nutr. 1995;125:1401.

9. Patterson,JA, Burkholder KM. Application of prebiotics and probiotics in poultry production. J. Poult. Sci. 2003;2:627.

10. Zhang ZF, Kim IH. Effects of probiotic supplementation in different energy and nutrient density diets on performance, egg quality, excreta microflora, excreta noxious gas emission, and serum cholesterol concentrations in laying hens. J. Ani. Sci. 2013;91:4781.

11. Kabir SLM. The Role of probiotics in the poultry industry. Fed. EU. Microbiol. Soc. 2009;10:3531.

12. Ditta YA, King AJ. Recent advances in sunflower seed meal as an alternate source of protein in broilers. Worlds' Poult. Sci. J. $2017 ; 73: 527$.

13. National Research Council. Nutrient Requirment of Poultry. 9th Revised Edition. Washington, DC: The National Academic Press. 1994. https://doi.org/10.17226/214.

14. Butcher GB, Miles RD. Egg Specific Gravity-Designing a Monitoring Program 1. IFAS Extesnion, University of Florida. https://edis.ifas.ufl.edu/pdffiles/VM/VM04400.pdf

15. Stino FKR, Goher NE, Gar K, Hanash NA. The effect of breed and housing system on the egg quality of white baladi and fayoumi hens in the sub tropics. Egypt. J. Ani. Prod. 1982;23:91.

16. Rath PK, Mishra PK, Mallick BK, Behura NC. Evaluation of different egg quality traits and interpretation of their mode of inheritance in White Leghorns. Vet. World. 2015;8:449.

17. Helena B, Kamila M; Zdenka, P. Evaluation of egg yolk colour. Czec. J. Food Sci. 2014;32:213.

18. EL-Wandary AM, Goher LM, Enab AA. Effect of breed, laying period and selection for egg weight on egg quality for two local breeds of chicken. Egyp. Poult. Sci. 1994;14:23.

19. Victor H, Carver JS. The albumen index as a physical measurement of observed egg quality. J. Poult. Sci. 1936;15:141.

20. Haugh, RR. The Haugh unit for measuring egg quality. U. S. Egg Poult. Mag. 1937;43:552.

21. 22. Statistical Power Analysis - Statistics Solutions www.statisticssolutions.com > statistical-power-analysis SAS/STATß 14.1 User's Guide The MIXED Procedure. 2015. https://support.sas.com/documentation/onlinedoc/stat/141/mixed.pdf

22. Uwayjan MG, Azar EJ, Daghir NJ. Sunflower seed in laying hen rations. J. Poult Sci. 1983;62:1247.

23. Yalcın S, Zsoy BO, Erol H. Yeast culture supplementation to laying hen diets containing soybean meal or sunflower seed meal and its effect on performance, egg quality traits, and blood chemistry. J. Appl. Poult. Res. 2008;17:229.

24. Shi SR, Lu J, Tong HB, Zou JM, Wang KH. Effects of graded replacement of soybean meal by sunflower seed meal in laying hen diets on hen performance, egg quality, egg fatty acid composition, and cholesterol content. J. App. Poult. Res. 2012;21:367.

25. Mohan B, Kadirvel R, Bhaskaran M, Natarajan. A. Effect of probiotic supplementation on serum/yolk cholesterol and on egg shell thickness in layers. J. Brit. Poult. Sci. 1995;36:799.

26. Kurtoglu V, Kurtogluz F, Sekery E, Coskuny B, Baleviy T, Polaty ES. Effect of probiotic supplementation of laying hen diets on yield performance and serum and egg yolk cholesterol. Food Add. Contam. 2004;21:817.

27. Yörük MA, Gül M, Hayirli A, Macit M. The effects of supplementation of humate and probiotic on egg production and quality parameters during the late laying period in hens. Poult. Sci. 2004;83:84.

28. Abdelgader, A.; Irshaid, R.; Al-fataftah A-R. Effect of dietary probiotic inclusion on performance, egg shell quality, cecal microflora composition, and tibia traits of laying hens in the late phase of production. Trop. Ani. Health Prod. 2013;45:

29. Karunajeewa H, Than SH, Abu-Serewa S. Sunflower seed meal, sunflower oil and full-fat sunflower seeds, hulls and kernels for laying hens. Ani. Feed Sci. Technol.1989;26:45.

30. Pizzolante CC, Saldanha ESPB, Laganá C, Kakimoto SK, Togashi CK. Effects of calcium levels and limestone particle size on the egg quality of semi-heavy layers in their second production cycle. Braz. J. Poult. Sci. 2009;11:79-86.

31. 33. Foster WH,Weatherup STC. The use of specific gravity of the egg to estimate shell thickness. Brit. Poult. Sci. 2007;20:439.

32. Stadelman, W.I.; Cot3erill, O.J. Egg Science and Technology, AVI Publishing Company, Co., USA, 1995.

33. Park J-A, Sohn S-H. The Influence of hen aging on eggshell and shell mineral components. Kor. J. Food Sci. 2018;38:1080.

34. Sarica M, Onder H, Yamak USDetermining the most effective variables for egg quality traits of five hen genotypes. Internation'l J. Agri. Bio. 2012;14:235. 
35. Mountzouris KC, Tsitrsikos P, Palamidi I; Arvaniti A, Mohnl M, Schatzmayr G, Fegueros K. Effects of probiotic inclusion levels in broiler nutrition on growth performance, nutrient digestibility, plasma immunoglobulins, and cecal microflora composition. J. Poult. Sci. $2010 ; 89: 58$.

36. Slavin J. Fiber and prebiotics: Mechanisms and health benefits. Nutrs. 2018;5: Pedroza G, Famula T, King A. Brocoli meal fed to laying hens increases nutrients in eggs and deepens the yolk color. CA Ag. 2018;72:243.

37. Kljak K, Grbesa D, Karolyi D. Estimation of carotenoid content from colour analysis of corn grits. Cro. J. Food Tech., Biotech. and Nutr. 2009;63:23. 